\title{
GENDER CONDITIONALITY OF ENVY
}

\author{
Tereza Kimplová, \& Lucia Lacková \\ University of Ostrava (Czech Republic)
}

\begin{abstract}
Whether a man or a woman, it is very important into what culture, time and country you are born in order to live a happy and fulfilled life. Gender stereotypes in various cultures and social relationships often inhibit living according to one's own ideas which can affect the quality of life or health. Within the university psychology education (University of Ostrava, Faculty of Education, Czech Republic), we asked 20 study groups (approx. 600 people, out of which 100 were men) two questions: 1) Are men more envious of men than women of women? 2) What do you envy in the opposite gender? A discussion usually followed lasting throughout the whole gender-focused seminar and we recorded the answers. The results imply that women experience envy in more areas, recognizing that men have a greater level of freedom of expression in various environments, which causes women to experience negative emotions due to such findings. Unfortunately, we also recorded a trend of deep and primary biological-psychological topics departing from the substance given by gender, for example that women would give up their ability to give birth (in "favour" of men). The men usually came up with inspiring reflections on perceiving the men's and women's world than primarily with envy, or grudge. The survey provided plentiful topics for further lessons and research where we are currently improving the quality of quantitative data collected thanks to a more precise methodology.
\end{abstract}

Keywords: Gender, education, envy, self-esteem, Czech Republic.

\section{Introduction}

Gender is a term used to describe culturally and socially established differences between men and women. In short, gender stereotypes and prejudices assign different traits and life roles to men and women in relation to their sex. They differ and change (or persist) over generations in various cultures and in relation to the social relations. In the Czech Republic, for example, there is still a belief that women should take care of the household and children and the model of femininity is a meek and gentle being, satisfying the needs of others. Men are perceived as the breadwinners, technically competent, good drivers, and their role is based on success and competitiveness. These inappropriate gender stereotypes do not only deny people to live their lives according to their own notions, but they may lead to more serious health-related consequences, such as bulimia or mental anorexia (due to the stereotype that girls should be slim and look like the current ideal of beauty, often unreasonable) or other serious psychological or even psychiatric disorders, caused, for example, by not being able to express one's emotions without being mocked in case of men (especially sadness through crying) and release one's aggression or tension in this way. At the same time, there has been a pressure to change these stereotypes, which is also bringing a considerable level of stress. For instance, it is stressful for men to maintain the "status" of a breadwinner, protector, competent fighter, while transforming into a sensitive father who takes care of his wife and children, and participates in household chores. This is a very popular topic with which we go into greater detail in our seminar on Family Psychology for Future Elementary and High School Teachers bringing interesting and even heated discussion. Lately, the seminars are more and more visited by men and we notice highly satisfactory transformations of roles, or changes in the thinking of men and women, at least those in the university environment focused on humanities. In case of men, this transformation is in favor of more natural expressions of emotions without feeling ashamed, better self-awareness and focus on a more specific division of roles in the household. Paradoxically, it is often women who call for equality of roles - especially at home and at work - while actually conforming to the "male" (even a bit "sociopathic") traits, and when a man emancipates himself, he is often called by women (and society) to be "hen-pecked" because the women have acquired the image of an "ideal man" either from their original families, or from the media. This way, the stereotype of a "macho" (who will never help around the house or with children) is being preserved. And once again, women - mothers are those who provide their sons with the perfect service (unlike daughters who are taught to satisfy the needs of others, especially of men, before their own) in the form of keeping their closets and rooms neat and 
serving warm dinners long into their adulthood and then they are surprised when they demand the same from their wives, or that their wives do not provide such a service to their sons. Such marriages are not usually very peaceful. In spite of that, the results of surveys of subjectively perceived quality of life state that there is no difference between the satisfaction of men and women - both at work and in their personal lives (such as Čadová, N. (2018). How can this contradiction be explained?

\section{Design}

Twenty study groups of the Family Psychology seminar from various fields of study, especially at the Faculty of Education (but also from the Faculties of Medicine, Sciences, Art and Social Studies) participated in the study. In total, we collected data from 600 students, out of which 100 were men. The students were asked two questions. The first one, establishing atmosphere, focused on a contemplation of the definition of envy and its types, what the students think about whether men are more envious of other men than women of other women and what they envied (and whom) when they were children etc. The second question focused on "what do you envy in the opposite sex?" The answers were recorded and later classified according to their frequency.

\section{Objectives}

The objective of the study was to present students with another topic for discussion regarding gender stereotypes based on the answers. We were interested in finding out whether or not the students can recognize what is determined and what is influenced by gender. And what are their attitudes?

\section{Methods}

The students were asked whether they think that men envy other men more or women envy other women and why. Then, we developed a discussion about the object of envy from their childhood. The key question followed: What do you envy in the opposite sex?

\section{Results}

We recorded all the answers and sorted them out according to frequency (from most common to the least represented). We obtained the following results.

Women (envy in men the following):

- Their lives are simply easier

- They do not have to birth children

- They do not menstruate

- They do not have to serve in the army anymore

- Type of friendships

- Carelessness

- They play all the time

- They do not have to deal with most household chores

- More free time

- Freer life ("I am afraid to go out after dark; I couldn't go outside like my brother when I was a child")

- They do not have to put on makeup (take care of their appearance as much)

- They can pee standing

- Peeing (everywhere)

- They argue and have a fight and then it's okay but women are always trying to resolve problems

- Strength

- Better job opportunities

- I don't know

- Nothing

Men (envy in women the following):

- NOTHING

- Empathy, sensibility (they are like that and they can express it)

- Natural approach to children ("I have to learn how to do it")

- It's easier for them, every man helps them when they smile

- They get what they want by manipulating men but I have to work hard to get what I want

- Women are taken into consideration more than men

- The child/mother relationship in the first year of life 


\section{Discussion}

It is obvious that the list of women's "envies" is much more extensive and the frequency of answers was represented more equally than in men's answers where "nothing" prevailed and the remaining answers followed with a large gap. This is probably also given by the considerable dominance and eloquence of female students as men were in a minority at the seminars (the discussion had to be carefully moderated), however, the topics and the course of the seminar were similar with each group. There were even moments of high tension, or even resentment, especially on the part of women against men who tried to dispute some of the things that the women mentioned. On the other hand, the men often agreed with the women's conclusions and stated that women do have a more difficult life. An interested finding was that the women found it difficult to differentiate between the biological and gender substance of the phenomena. They resigned to assign everything to biology, i.e. that a woman is predetermined to have a more complicated life. On the contrary, men in some humanity studies were able to reflect (we take into account that this was a specific university population) that the situation in equal opportunities should change and they were not as aware of the obvious impact of media (especially advertising) on the male (a man as a hero, breadwinner, or a "dummy" with a bit of a cold as lately proclaimed in advertisements) and female roles (a woman as a "shrew" against men, a sexual object, a child-minder, an ideal capable mother-wife-manager). On the other hand, the fact that men did not mention more things does not mean that men are not as envious of women, maybe they just did not say what they wanted to, which is in compliance with the gender stereotype of a "hero" who never complains. However, it was perplexing to hear women state that they envy men because they do not have to birth children and deal with menstruation. This fact deeply reflects the sociocultural perception of a woman (and a man), as well as the strong, inner imbalance and low confidence in femininity itself. The question arises whether and how would these answers change in the course of their lives, or whether or not they depend on the type and level of education and so on. Based on these examinations in our seminars, we continue to ask the following question: how is it possible that statistically women in surveys are as subjectively satisfied in various areas of life as men? Because if that is true, then the likelihood of a change is very low.

The methodological aspect of the study is a critical point and we are aware of the weaknesses. However, we have to take into account that the primary objective was educational and that the originally intended simple method was sufficient for this purpose. We decided to sort out and publish the answers of the participants with regard to the complex and topically recurring views and in the future, we will process the data in a more sophisticated way.

\section{Conclusions}

Young women and men, in the case of our sample of mostly future elementary and high school teachers, have a lot to say about gender stereotypes. It turned out that women's envy with regard to the perceived advantages of "being a man" is quite high and it often conceals remorse or anger, and definitely accumulated emotions. Gender is often confused with biological predetermination and the related powerlessness in changing anything. As a result, women disrespect their biological essence and consider their foundation to be a burden. Incidentally, could this be one of the reasons of Europe's low birthrate? Parenting, education in schools and the impact of media often promotes gender stereotypes - both in men and women. Elementary and high schools lack a subject on partnership and parenting, there is only sexual education. In families, there is often a lack of a model father figure and family relations disintegrate. It is quite obvious that we are going through a period of relationship transformation and that there is still a lot to do in the field of the roles of men and women.

\section{References}

Čadová, N. (2018). Subjektivní vnímání životní spokojenosti u ekonomicky aktivní populace České republiky [Online]. Retrieved from https:/www.bozpinfo.cz/josra/subjektivni-vnimani-zivotnispokojenosti-u-ekonomicky-aktivni-populace-ceske-republiky

Kimplová, T. (2018). Vybrané kapitoly z psychologie rodiny. Ostrava: Ostravská univerzita.

Maussen, J., \&, a kol. (2018). Shrnutí závěrečných zpráv expertních skupin pro identifikaci relevantních indikátorů kvality života $\mathrm{v} \quad \check{\mathrm{C}} \mathrm{R}$ [Online], 47. Retrieved from https://www.vlada.cz/assets/ppov/udrzitelny-rozvoj/projekt-OPZ/Kvalita-zivota-shrnuti.pdf

Oakleyová, A. (2000). Pohlaví, gender a společnost. Praha: Portál.

Raewyn, C. (2014). Gender. Polity Press.

Schoepke, J., Hoonakker, P. L. T., \& Carayon, P. (2004). Quality of Working Life among Women and Men in the Information Technology Workforce [Online], 6. https://doi.org/10.1177/154193120404801404 